\title{
PEMANFAATAN TANAH ULAYAT UNTUK PENDIRIAN TONDOK DI KABUPATEN MAMASA
}

\author{
Lisma Lumentut, Rantau Padallo \\ Univeristas Kristen Indonesia Paulus, lisma@ukipaulus.ac.id
}

\begin{abstract}
Abstrak
Pendirian Tondok merupakan salah satu proses pemanfaatan tanah hak ulayat di daerah Mamasa, namun pemanfaatan tanah hak ulayat tersebut belum diatur dalam suatu peraturan daerah Kabupaten Mamasa. Penelitian ini bertujuan untuk mengetahui bagaimana proses pemanfaatan tanah hak ulayat untuk pendirian Tondok di daerah Mamasa serta bagaimana status tanah yang ditempati oleh perorangan dalam Tondok. Penelitian ini menggunakan Yuridis Empiris dengan pendekatan sejarah dan kasus. Hasil penelitian ini menunjukkan bahwa dalam proses pemanfaatan tanah hak ulayat untuk pendirian Tondok di daerah Mamasa dilakukan atas persetujuan bersama oleh pimpinan adat dan warga masyarakat hukum adat Mamasa. Status tanah secara perseorangan dalam Tondok diakui sebagai hak bersama dan hak perorangan diakui secara terbatas karena dianggap hak pakai dan adanya larangan pengakuan tanah sebagai hak milik kecuali dalam bentuk sawah.
\end{abstract}

Kata Kunci : Tondok, Tanah Ulayat

\begin{abstract}
The establishment of Tondok is one of the process of utilization of land rights in Mamasa area, but the utilization of land rights is not regulated in a regional regulation of Mamasa Regency. This research aims to find out how the process of utilizing land rights ulayat for the establishment of Tondok in Mamasa area as well as how the status of land occupied by individuals in Tondok. This research uses Empirical Juridical with historical and case approaches. The results of this study show that in the process of utilizing land rights ulayat for the establishment of Tondok in Mamasa area was carried out on mutual consent by indigenous leaders and citizens of mamasa indigenous law community. The status of land individually in Tondok is recognized as a joint right and the rights of individuals are recognized in a limited way because it is considered a right of use and the prohibition of the recognition of land as property except in the form of rice fields.
\end{abstract}

Keywords : Tondok, Ulayat Land

\section{Pendahuluan}

Manusia dan Tanah mempunyai hubungan yang erat. Selain untuk kepentingannya sendiri, tanah juga dibutuhkan untuk kepentingan yang lebih luas dimana Tanah adalah kebutuhan, manusia selalu berusaha untuk memilikinya, merupakan kenyataan sekalipun ada juga yang tidak pernah memiliki tanah. Kebutuhan tanah yang bersifat pokok maka tanah mempunyai kedudukan yang tinggi bagi manusia, sebagai tempat ia dilahirkan, dibesarkan, membangun kehidupannya sebagai tempat tinggal, sebagai sumber nafkah, dan juga sudah meninggal dunia kemudian.

Di Negara agraris seperti Indonesia, tanah merupakan salah satu unsur dari alam yang mempunyai fungsi amat penting bagi kemakmuran dan kesejahtraan rakyat. Fungsi tanah tersebut dapat dilihat dari berbagai sudut pandang, salah 
satunya adalah Hak ulayat yang merupakan bagian dari salah satu hak atas tanah menurut Hukum Adat Di Indonesia.

Hak Ulayat merupakan serangkaian wewenang dan kewajiban suatu masyarakat hukum adat, yang berhubungan dengan tanah yang terletak dalam lingkungan wilayahnya, yang sebagai telah diuraikan di atas merupakan pendukung utama penghidupan dan kehidupan masyarakat yang bersangkutan sepanjang masa.

Konsepsi hak ulayat menurut hukum adat terdapat nilai-nilai komunalistikreligius-magis yang memberi peluang penguasaan tanah secara individual, serta hakhak yang bersifat pribadi. Namun, demikian hak ulayat bukan hak orang-perorang. Sehingga dapat dikatakan hak ulayat bersifat komunalistik karena hak itu merupakan hak bersama anggota masyarakat hukum adat atas tanah yang bersangkutan. Sifat magis-religius menunjuk kepada hak ulayat tersebut merupakan tanah milik bersama, yang diyakini sebagai sesuatu yang memiliki sifat gaib dan merupakan peninggalan nenek moyang dan para leluhur pada kelompok masyarakat adat itu sebagai unsur terpenting bagi kehidupan dan penghidupan mereka sepanjang masa dan sepanjang kehidupan itu berlangsung. Jika dilihat dari sistem hukum tanah adat tersebut, maka hak ulayat dapat mempunyai kekuatan berlaku kedalam dan keluar.

Ke dalam berhubungan dengan para warganya, sedang kekuatan berlaku keluar dalam hubungannya dengan bukan anggota masyarakat hukum adatnya, yang disebut "orang asing atau orang luar". Kewajiban utama penguasa adat yang bersumber pada hak ulayat ialah memelihara kesejahteraan dan kepentingan anggota-anggota masyarakat hukumnya, menjaga jangan sampai timbul perselisihan mengenai penguasaan dan pemakaian tanah dan kalau terjadi sengketa ia wajib menyelesaikan. Akan tetapi untuk hak ulayat yang mempunyai kekuatan berlaku ke luar hak ulayat dipertahankan dan dilaksanakan oleh penguasa adat masyarakat hukum adat yang bersangkutan. ${ }^{1}$

Istilah "hak ulayat" dijumpai dalam Pasal 13 UUPA, namun tidak ada satu rumusan pengertian hak ulayat secara jelas. Di dalam Pasal 3 UUPA hanya memberikan kepastian bahwa hak ulayat atau hak serupa itu menurut kenyataannya masih dikakui eksistensinya sehingga lebih lanjut hak ulayat itu harus diperhatikan dan dihormati. Dalam penjelasan Pasal 3 UUPA hanya disebutkan bahwa hak ulayat dan hak-hak yang serupa itu ialah "beschikkingsrecht". Demikian juga di dalam penjelasan rinci tentang pengertian hak masyarakat hukum adat, di sini hanya menegaskan tentang pengakuan hak ulayat dari kesatuan masyarakat adat dan akan didudukkan hak ulayat tersebut pada tempat yang sewajarnya.

Berkaitan dengan Hak Ulayat, maka masyarakat adat Mamasa juga tidak terlepas dari itu karena Masyarakat adat Mamasa yang secara turun-temurun hidup

\footnotetext{
1 Harsono Budi, 1997. Hukum Agraria, sejarah pembentukan UndangUndang Pokok Agrarian, Isi pelaksanaannya, Djambatan, Jakarta, hal. 55
} 
dalam suatu teritorial dengan sistem sosial, institusi, kebiasaan dan hukum adat sendiri. Berkaitan dengan kebiasaan ini masyarakat hukum adat Mamasa juga mengenal tentang hak ulayat sebagai wujud dari kewenangan masyarakat adat Mamasa atas tanah di mana hak ulayat ini sering di sebut dengan Litak adat, dan jika diterjemahkan kedalam bahasa Indonesia berarti Tanah adat dimana masyarakat adat Mamasa memilik hak untuk memanfaatkan Litak adat ini dan salah satunya adalah untuk pendirian Tondok atau tempat pemukiman warga masyarakat adat Mamasa.

Tondok yaitu suatu daerah di mana masyarakat hukum adat Mamasa menetap dalam suatu wilayah adat sehingga terbentuk suatu persekutuan hukum adat di mana masyarakat yang tinggal menetap dalam Tondok akan terikat dengan kebiasaan setempat, jika di artikan dalam bahasa modern, maka Tondok adalah sebuah Dusun yang merupakan bagian dari wilayah Desa yang merupakan lingkungan kerja pelaksanaan pemerintahan Desa sesuai dengan penjelasan pada Pasal 1 huruf c UU No.5 Tahun 1979 tentang Pemerintahan Desa, dijelaskan lebih jauh dalam Pasal 8 UU Pemerintahan Desa bahwa dusun dapat disebut dengan nama lain yang disesuaikan dengan asal usul, adat istiadat, dan nilai sosial budaya masyarakat Desa sehingga melalui dasar hukum inilah sehingga masyarakat hukum adat Mamasa menyebutnya dengan kata Tondok. Pemukiman ini biasanya akan di resmikan dengan istilah Diraruk atau peresmian secara bersama-sama oleh masyarakat hukum adat Mamasa yang di hadiri para tokoh masyarakat hukum adat Mamasa, seiring dengan perkembangan zaman banyak oknum masyarakat hukum adat Mamasa yang tinggal dalam Tondok ingin mengklaim tanah yang ada di dalam Tondok ini dengan status hak milik secara individu tetapi tomatua atau para tokoh adat menolak bersama dengan penduduk di dalam Tondok itu. Berdasarkan latar belakang tersebut maka latar belakang yang akan diteliti adalah Bagaimana proses pemanfaatan tanah Hak ulayat untuk pendirian Tondok dan Bagaimana status tanah yang di tempati oleh perorangan dalam Tondok.

\section{Metode}

Jenis dari penelitian yang digunakan adalah Yurisidis Empiris dimana penulis menganalisis permasalahan yang dilakukan dengan cara memadukan antara bahanbahan hukum (Sekunder) dan Data Primer yang diperoleh di lapangan. Data primer, yaitu data yang diperoleh dari hasil wawancara dengan pihak Responden dan Informan. Data sekunder, yaitu data yang diperoleh dari bahan hukum Jurnal, dokumen, hasil karya tulis ilmiah, artikel artikel, dan perundang-undangan. Sesuai dengan permasalahan yang diteliti dalam Skripsi ini maka penulis melakukan pengumpulan data dengan Telaah Pustaka yang dilakukan penulis dengan kajian mendalam atas pembahasan suatu buku, Jurnal, dokumen, hasil karya tulis ilmiah, dan artikel artikel Ilmuan yang telah diakui. Wawancara yang dilakukan penulis dengan cara turun langsung ke lapangan untuk melakukan penelitian dengan 
mengajukan pertanyaan kepada para narasumber sebagai bahan utama sumber penelitian hukum tidak tertulis ini. Data primer dan sekunder yang diperoleh dalam penelitian ini dan dianalisis secara kuantitatif, kemudian dilakukan deskripsi yaitu menjelaskan kenyataan, peristiwa-peristiwa, orang-orang dan interkasi yang diamati.

\section{Proses pemanfaatan tanah Hak ulayat untuk pendirian Tondok}

Jika melihat dari segi pengakuan Negara saat ini, maka yang menjadi dasar adalah Pasal 33 ayat 3 UUD 1945 "bumi, air dan kekayaan alam yang terkandung didalamnya dikuasai oleh Negara dan dipergunakan sebesar-besarnya demi kemakmuran rakyat". Pengakuan hak ulayat juga terdapat dalam Pasal 18B ayat (2) UUD 1945 yang menyakatan bahwa Negara mengakui dan menghormati kesatuankesatuan masyarakat hukum adat beserta hak-hak tradisionalnya sepanjang masih hidup dan sesuai dengan perkembangan masyarakat dan prinsip Negara Kesatuan Republik Indonesia, yang diatur dalam undang-undang dan pada dasarnya sumber pengakuan itu tidak terlepas dari hak menguasai Negara.

Pada Pasal 2 ayat (1) UUPA disebutkan bahwa Negara adalah organisasi kekuasaan seluruh rakyat Indonesia. Hal ini berarti bahwa bangsa Indonesia membentuk Negara Republik Indonesia untuk melindungi segenap tanah air Indonesia dan melaksanakan tujuan bangsa Indonesia untuk memajukan kesejahteraan umum.

Untuk melaksanakan tujuan tersebut Negara Republik Indonesia mempunyai hubungan hukum dengan tanah diseluruh wilayah Indonesia agar dapat memimpin dan mengatur tanah di seluruh wilayah Negara Republik Indonesia maka atas nama bangsa Indonesia melalui peraturan perundang-undangan, yaiu UUPA dan peraturan pelaksanaannya.

Hubungan hukum tersebutlah yang dinamakan hak menguasai Negara. Hak ini tidak diberi kewenangan untuk menguasai secara fisik dan menggunakannya seperti hak atas tanah karena sifatnya semata-mata sebagai kewenangan publik sebagaimana dirumuskan dalam pasal 2. ${ }^{2}$

Penundukan pemberlakuan hukum adat terhadap hukum Negara menunjukkan bahwa Negara perlu mengatur hukum yang berlaku di dalam wilayahnya. Bagi Indonesia, hak tersebut sesuai dengan salah satu pilihan bahwa pilihan hukum adat di bawah ketentuan hukum undang-undang maka keberadaan hukum adat yang dalam kaitannya dengan hak ulayat disertkana pada pengaturan undang-undang atau Hukum Negara. ${ }^{3}$

\footnotetext{
${ }^{2}$ Hutagalung Arie Sukanti dan, Gunawan Markus, 2008. KewenanganPemerintah di Bidang Pertanahan, Rajawali Press, Jakarta, hal.23

${ }^{3}$ Husen Alting, 2011. Dinamika Hukum dalam Pengaktian dun Perlindungan Hak Masyarakat hukum Adat Atas Tanah, Laksbang Pressindo, Yogyakarta, hal.67
} 
Berlakunya hukum adat dalam kaitannya dengan hak ulayat harus tidak mengandung unsur bertentangan dengan peraturan perundang-undangan Negara, konsep inilah yang dijadikan UUPA dimana hukum adat dianggap terdapat kekurangan yang harus dibersihkan dengan menggunakan kriteria hukum nasional. Jadi, hukum nasional dianggap sebagai superior dibandingkan dengan hukum adat.

Sejak awal pembukaan lahan hingga peresmian Tondok merupakan salah satu bukti bahwa wilayah Tondok hingga saat ini adalah hak komunal mereka secara turun-temurun. Dalam Pasal 3 UUPA dijelaskan bahwa hak ulayat ini akan diakui selama kenyataanya masih ada dan diberlakukan masyarakat adat setempat seperti di daerah Mamasa.

UUPA sendiri sengaja tidak mengadakan pengaturan lebih jauh dalam bentuk peraturan perundang-undangan mengenai hak ulayat, sehingga dalam keadaan ini ada keuntungan secara tidak langsung bagi masyarakat adat karena akan memberikan kebebasan dalam pengaturannya berlangsung sesuai hukum adat setempat tetapi di sisi lain akan menghambat perkembangan secara alami hak ulayat, hal ini dipercepat karena semakin kuatnya hak-hak individu melalui pengaturannya dalam bentuk hukum tertulis yang menghasilkan surat tanda bukti hak. ${ }^{4}$

Secara konseptual hak ulayat merupakan hak tertinggi dalam sistem hukum adat. Dibawah hak ulayat hak kepala atau tetua adat yang merupakan turunan hak ulayat dan semata-mata beraspek hukum publik. Selanjutnya barulah hak-hak individual yang secara langsung maupun tidak langsung juga bersumber dari hak ulayat yang beraspek hukum keperdataan. Namun demikian, meskipun dalam bidang hukum keperdataan, pengaturan penguasaan dan penggunaannya ditentukan oleh kepala adat tersebut, yang termasuk bidang hukum publik. ${ }^{5}$

Keberadaan tanah hak ulayat bagi masyarakat hukum adat Mamasa karena adanya kesepakatan bersama untuk menetap dalam suatu wilayah adat yang disebut Tondok, di mana keadaan ini merupakan salah satu ciri khas dari masyarakat adat pada umumnya di seluruh wilayah Indonesia, hak ulayat ini merupakan serangkaian wewenang dan kewajiban masyarakat adat dalam suatu wilayahnya yang merupakan tanah hak ulayatnya. Wewenang yang dimaksud berisi tentang hak dan kewajiban masyarakat adat tersebut yang timbul dari hubungan secara lahiriah dan batiniah sebagai akibat hubungan dengan tanah dan telah berlangsung secara turun-temurun. Hubungan tersebut melahirkan hak masyarakat adat atas tanah, yakni menguasai tanah dan segala isinya.

Pendirian Tondok ini dilatar belakangi dengan adanya pemikiran dari orang banyak untuk menetap bersama dalam satu Tondok, dalam falsafah hidup

\footnotetext{
${ }^{4}$ Harsono Boedi, 2007. Hukum Agraria Indonesia, Sejarah Pembentukan Undang- Undang Pokok agraria, Isi dan Pelaksanaannya, Djambatan, Jakarta, hal.193

${ }^{5}$ Nurlinda Ida, 2009. Prinsip-Prinsp Pembaruan Agraria Perspektif Hukum, Rajawali Pers, Jakarta, hal.71
} 
masyarakat hukum adat Mamasa awalnya mereka hidup terpisah dengan jarak yang berbeda-beda tetapi mereka berfikir bahwa alangkah baikanya jika mereka hidup bersama-sama dalam suatu lingkungan secara kolektif agar bisa hidup secara berdampingan, karena secara tidak langsung mereka sadar bahwa manusia adalah makhluk sosial yang selalu saling membutuhkan, sehingga dalam proses pendirian suatu Tondok mengenal tiga tahap penyelesaian yaitu Parrabangan, Parrarukan, dan Melambe dimana tahap ini harus dilalui secara berurutan.

Parrabangan adalah kegiatan membersihkan hutan yang dilakukan untuk lokasi perkampungan dalam proses ini akan disediakan satu ekor ayam untuk di sembelih dan darahnya sebagai bukti perjanjian bersama masyarakat hukum adat mamasa dan setelah hutan itu dibersihkan maka masyarakat yang ingin tinggal dan menetap secara bersama-sama bebas untuk menentukan lokasi rumah di dalam Tondok yang sudah di bersihkan itu.

Parrarukan dilakukan melalui yang dituakan sebagai pimpinan adat atau dalam istilah masyarakat hukum adat Mamasa Tomatua Tondok mengelilingi batas lokasi tersebut dengan membawa seekor anjing atau ma renden asu untuk mengelilingi batas lokasi sambil menanami batas tanah dengan beringin/barana, bambu/ao', bunga tabang/taba borrong, setelah sampai di titik awal keberangkatan maka anjing tersebut dipotong dan beras itu dimasak untuk dijadikan lauk dan dimakan bersama-sama, maka selesailah proses parrarukan sehingga resmilah sebagai Tondok.

Melambe adalah bentuk rasa syukur kepada Tuhan oleh masyarakat hukum adat Mamasa karena tanpa perteolongannya dan petunju dari Tuhan maka Tondok tidak ada selesai. Dalam tahap Melambe juga masyarakat hukum adat setempat yang ada di Tondok itu menentukan satu orang yang dituakan sebagai Tomatua Tondok atau pimpinan adat dalam Tondok dan Petoe Piso yaitu orang yang bertugas sebagai tukang penyembelih hewan dalam setiap kegiatan ritual yang dilakukan dalam Tondok yang sekaligus menentukan sumur umum untuk air bersih, dalam istilah Mamasa sumur umum ini disebut dengan Timbu.

\section{Status tanah yang di tempati oleh perorangan dalam Tondok}

Tanah dalam Tondok merupkan hak ulayat seperti yang jika dijelaskan Mustari Pide bahwa hak ulayat secara khas merupakan hubungan yang timbul secara secara lahirian dan batiniah, turun-temurun, dan tidak terputus antara masyarakat hukum adat dengan wilayahnya sehingga ini dapat diartikan sebagai hubungan menguasai. ${ }^{6}$ Dijelaskan lebih jauh oleh Rosnidar Sembiring bahwa di dalam hak ulayat tanah adat

\footnotetext{
${ }^{6}$ Mustari Pide Suriyaman, 2014. Hukum Adat, Dahulu Kini, Dan Akan Datang, Prenadan media, Jakarta, hal.123
} 
adalah penguasaan tertinggi atas tanah dalam hukum adat, sehingga lingkungan wilayah masyarakat adat itu merupakan tanah kepunyaan bersama oleh warganya. ${ }^{7}$

Status tanah dalam Tondok adalah kepemilikan bersama atau biasa disebut dalam istilah masyarakat hukum adat Mamasa Litak disola-solai, kepercayaan ini tidak terlepas dari keyakinan bahwa nasehat itu yang harus pelihara karena ditinggalkan oleh leluhur mereka sejak dahulu hingga sekarang, ini dibuktikan dengan penjelasan sebelumnya tentang Parrabangan, Parrarukan, hingga Melambe yang sudah dianggap sebagai hukum kebiasaan, dan warisan secara turun-temurun dari leluhur masyarakat hukum adat Mamasa di Tondok Batarirak sehingga masyarakat hukum adat Mamasa hingga saat ini merasa terikat, semua berawal dari tindakan kesepakatan leluhur mereka dengan bukti dipato'doi rara yang artinya bukti dengan penetesan darah sehingga bermakna sakralnya atau suci karena jika ada yang ingin melanggar maka dipercayai masyarakat hukum adat Mamasa dapat mendatangkan malapetaka atau musibah.

Status tanah dalam Tondok ini diakui masyarakat hukum adat Mamasa hanya sebagai sebatas hak pakai atas tanah di wilayah Tondok tersebut, yang sebelumnya telah Diraruk atau diberi batas dimana bukti hak pakai tersebut adalah pendirian suatu bangunan atau bisa dalam bentuk pengolahan kebun ataupun berternak tetapi pengakuan hak pakai ini ada pengecualian ketika diolah sebagai umah/sawah yang dianggap merupakan hak miliknya dari turun-temurum atau dalam bahasa Mamasa disebut anunna tomatuanna, dijelasakan oleh Boedi Harsono bahwa penguasaan tanah dalam suatu wilayah hukum adat, awalnya digunakan atau dipakai untuk memenuhi kebutuhan secara pribadi dan keluarganya yang bersifat sementara atau tanpa batasan waktu. ${ }^{8}$ Batas pemenuhan kebutuhan inilah yang tidak diatur oleh masyarakat hukum adat dalam Tondok, sehingga menurut Boedi Harsono dapat disebut dengan hak milik tetapi masyarakat dalam Tondok hak milik hanya diakui secara terbatas karena ada pengeculian jika pengolahan dalam bentuk umah/sawah dalam Litak Tondok, dan dijelasakan lebih jauh oleh Boedi Harsono bahwa dalam hubungan timbal antara hak ulayat dengan hak-hak perseorangan semakin banyak usaha yang dilakukan seseorang atas suatu bidang tanah maka hubungannya aka semakin erat, haknya atas tanah tersebut semakin kuat. ${ }^{9}$ Tanah dalam Tondok dapat juga dipakai sebagai perjanjian meyangkut tanah tetapi hanya sebatas tanah yang dikuasai secara perorangan tersebut dalam bentuk sawah atau umah/sawah dalam bahasa Mamasa, bentuk perjanjiannya adalah bagi hasil dimana perjanjian itu dapat dilakukan dengan sesama orang yang tinggal dalam Tondok yang sama dengan

\footnotetext{
${ }^{7}$ Sembiring Rosnidar, 2017. Hukum Pertanahan Adat, Jilid I, Raja Persada, Depok, hal.19

${ }^{8}$ Harsono Boedi, 2007. Hukum Agraria Indonesia, Sejarah Pembentukan Undang- Undang Pokok agraria, Isi dan Pelaksanaannya, Djambatan, Jakarta, hal.181

${ }^{9}$ Harsono Boedi, 2007. Hukum Agraria Indonesia, Sejarah Pembentukan Undang- Undang Pokok agraria, Isi dan Pelaksanaannya, Djambatan, Jakarta, hal.188
} 
disebut Dipa'petesanan dalam bahasa Mamasa, sehingga hak perseorang tanah tersebut harus berbentuk sawah yang diberikan kepada orang lain untuk digarap atau diolah dan hasil padinya mereka bagi dua atau disebut dalam bahasa Mamasa $n a$ pa'dua to ma'uma anna ton tesan ni padan na situru' yanni, karena status umah/sawah dianggap sebagai hak milik secara turun-temurun maka dalam penjelasan nenek deppauta bahwa umah/sawa ini dapat juga di pa'peta'gasan atau di gadaikan sehingga hasilnya akan ambil secara penuh oleh pihak kreditur sebagai orang yang memiliki hak atas benda jaminan tersebut, umah/sawa ini juga dapat dijual atau dalam bahasa Mamasa mala dibaluk karena seperti yang dijelaskan oleh ambe Simon gayang bahwa anunna kaia solata aka ya ungkarang ngi yang artinya bahwa tanah tersebut adalah miliknya secara sah karena adanya pengeolaha sebagai umah/sawah.

Meskipun ada status tanah perorangan dalam Tondok tetapi dalam wilayah suatu Tondok secara keseluruhan sampai saat ini hak ulayatnya tidak hilang karena pada umumnya masyarakat hukum adat Mamasa yang tinggal dalam suatu Tondok tetap mengakui dan menganggap bahwa tanah kering yang mereka kuasai secara perorangan hanya sebatas dipakai, pengakuan ini dibuktikan dengan tidak adanya pendaftaran tanah hak milik masyarakat hukum adat seperti dalam Tondok Batarirak, tindakan ini dilarang karena mereka tidak ingin ada yang memperjual belikan tanah dalam wilayah Tondok yang merupakan bagian dari Litak Tondok tersebut, dan alasan utama larangan dapat dilakukannya pendaftaran tanah di wilayah dalam Tondok karena adanya kekawatiran jika ada oknum masyarakat adat yang tinggal dalam Tondok menjual tanah hak miliknya dalam wilayah Tondok tersebut, karena masyarakat hukum adat setempat memikirkan generasinya bahwa akan ada anak dan cucu mereka sehingga apa jadinya jika tanah dalam suatu Tondok sudah habis dijual maka keturunan mereka suatu saat nanti akan terpisah dalam menetap karena mereka sudah tidak memilik warisan tanah sebelumnya dari nenek moyang dan orang tuanya.

Larangan ini memang perlu demi pencegahan tersebut tetapi disisi lain jika melihat dari segi peraturan perundang-undangan maka dalam Pasal 19 UUPA menjelaskan bahwa untuk menjamin kepastian hukum maka perlu adanya pendaftaran tanah hak milik pada setiap tanah yang dikuasai secara perorangan, dalam PP No.24 tahun 1997 tentang pendaftaran tanah Pasal 24 ayat (2) menegaskan bahwa seseorang yang menguasai fisik tanah selama kurung waktu 20 tahun secara terus-menerus dapat mendaftarkan diri sebagai pemegang hak atas tanah tersebut, dalam penguasaan tanah oleh masyarakat adat yang tinggal dalam Tondok telah dilakukan secara turun-temurun sehingga dapat dipastikan bahwa penguasaan tersebut sudah lebih dari 20 tahun sehingga dapat disimpulkan bahwa sebaiknya ada pendaftaran tanah demi adanya kepastian hukum. 
UU No.23 tahun 2014 menjelasakan bahwa Pemerintah Daerah telah di limpahkan kewenangan untuk mengatur daerahnya sendiri dengan seluas-luasnya berdasarkan asas otonom sepanjang tidak bertentangan dengan kepentingan pemerintah pusat, kewenangan ini akan sangat dapat mendorong dan mempertahankan beradaan masyarakat adat dan hak ulayatnya, dengan adanya peraturan daerah diharapkan mampu menghidupkan kembali keberagaman dan kearifan lokal yang ada pada masyarakat hukum adat di daerah sehingga hak ulayat akan mendapat pengakuan secara yuridis dari pemerintah daerah, mirisnya Pemerintah Daerah Kabupaten Mamasa belum menetapkan peraturan daerah tentang perlindungan ataupun pengakuan hak ulayat Tondok ini lebih jauh sehingga sampai saat ini umumnya Tondok di setiap wilayah Kabupaten Mamasa tidak ada yang didaftarkan demi mendapat pengakuan hak ulayat sesuai Permen Agraria No.9 Tahun 2015 sedangkan pada Tondok Batarirak misalnya telah memenuhi eksistensi keberadaan objek hak ulayat mereka di mana pada Tondok Batarirak seperti yang dijelaskan dalam Pasal 2 ayat (1) Permen Agraria tentang pengakuan hak komunal bahwa dapat dikukuhkan hak atas tanahnya, jika diuraikan dalam Pasal 3 Permen Agraria tersebut maka Tondok Batarirak telah memenuhi syarat sebagai paguyuban dimana masyarakat hukum adat Mamasa yang tinggal dalam Tondon Batarirak adalah terdiri dari satu keturun yaitu Nenek Deppa Lallo Pihak Lelaki dan Nenek Arruan Bamba pihak wanita, umumnya dalam Tondok di setiap wilayah kabupaten Mamasa juga dibentuk lembaga adat yang dalam Pasal 1 Peraturan Daerah No.5 Tahun 2017 Kabupaten Mamasa menyebutnya Lisuan Ada' di mana lembaga adat ini tumbuh dalam setiap Tondok di setiap wilayah Kabupaten Mamasa di mana anggota dalam Lisuan Ada' Lisuan Ada' dipilih oleh masyarakat hukum adat setempat dalam suatu Tondok, lebih jauh dijelaskan dalam Pasal 3 ayat (1) bagian c Permen Agraria yang sama bahwa harus ada wilayah hukum adat yang jelas dan dalam Tondon Batarirak salah satu fungsi adanya Parrukan adalah untuk menentukan batas wilayah dalam suatu Tondok, dalam Pasal 3 ayat (1) bagian d menjelaskan tentang adanya pranata hukum dan perangkat hukum yang masih ditaati dan dalam kenyataanya masyarakat hukum adat Mamasa yang tinggal dalam Tondon Batarirak tidak ada yang melakukan pendaftaran tanah hak milik sebagai bukti bahwa mereka masih taat dengan peraturan hukum adatnya sehingga jika melihat uraian diatas maka dapat disimpulkan bahwa Tondon Batarirak memenuhi syarat untuk diakui hak komunalnya bahwa dapat dikukuhkan hak atas tanahnya dan mendapat pengakuan hak ulayat.

\section{Kesimpulan}

Proses pengesahan Tondok dilakukan atas persetujuan bersama oleh pimpinan adat dan warga masyarakat hukum adat Mamasa yang ingin tinggal dalam Tondok tersebut, mulai dari tahap Parrabangan, Parrarukan, hingga Melambe dan juga bahan 
yang dipakai dikumpulkan secara bersama dan digunakan untuk proses pengesahan Tondok tersebut, Peruntukan awal pembukaan tanah dalam Tondok adalah tempat untuk menetap secara bersama dan sawah yang ditempati dikuasai secara bersama sebagai Litak Tondok. Hak perorangan diakui secara terbatas karena tanah tidak dapat diperjual belikan di Tondok Batarirak kecuali sawah yang diakui sebagai hak milik, sehingga pendaftaran tanah dilarang dalam masyarakat karena kekuatiran tanah hak milik dapat dialihkan dengan jual-beli. Status tanah secara perseorangan dalam Tondok diakui sebagai tanah bersama-sama dan hak perorangan dalam bentuk pendirian rumah, membuka tanah, memetik hasil hutan, mengambil kayu dan buah tumbuhan dalam hutan, dan berkebun diakui sebagai hak pakai kecuali sawah karena dianggap sebagai milik mereka secara turun-temurun. Atas sawah dapat dilakukan perjanjian bagi hasil, gadai, dan jual-beli.

\section{REFERENSI}

Harsono Budi, 1997. Hukum Agraria, Sejarah Pembentukan UndangUndang Pokok Agraria, Isi Pelaksanaannya, Jakarta: Djambatan.

Harsono Boedi, 2007. Hukum Agraria Indonesia, Sejarah Pembentukan Undang- Undang Pokok agraria, Isi dan Pelaksanaannya, Jakarta: Djambatan.

Hutagalung Arie Sukanti dan, Gunawan Markus, 2008. KewenanganPemerintah di Bidang Pertanahan, Jakarta : Rajawali Press.

Nurlinda Ida, 2009. Prinsip-Prinsp Pembaruan Agraria Perspektif Hukum, Jakarta: Rajawali Pers.

Husen Alting, 2011. Dinamika Hukum dalam Pengaktian dun Perlindungan Hak Masyarakat hukum Adat Atas Tanah, Yogyakarta: Laksbang Pressindo.

Mustari Pide Suriyaman, 2014. Hukum Adat, Dahulu Kini, Dan Akan Datang, Jakarta: Prenadan media.

Sembiring Rosnidar, 2017. Hukum Pertanahan Adat, Jilid I, Depok: Raja Persada. 